\title{
Reuse of Sintered Sludge from Municipal Sewage Treatment Plants for the Production of Lightweight Aggregate Building Mortar
}

\author{
Changyong Li ${ }^{1,2, * \mathbb{D}}$, Xiaoyan Zhang ${ }^{1,2}$, Bingxin Zhang ${ }^{1}$, Yunfei Tan ${ }^{3}$ and Fenglan Li ${ }^{1,2}$ (D) \\ 1 International Joint Research Lab for Eco-Building Materials and Engineering of Henan, \\ School of Civil Engineering and Communications, North China University of Water Resources and Electric \\ Power, Zhengzhou 450045, China; zxyanzi@ncwu.edu.cn (X.Z.); Z201710313234@stu.ncwu.edu.cn (B.Z.); \\ lifl64@ncwu.edu.cn (F.L.) \\ 2 Collaborative Innovation Center for Efficient Utilization of Water Resources, North China University of Water \\ Resources and Electric Power, Zhengzhou 450045, China \\ 3 Zhengzhou Wastewater Purification Co., Ltd., Zhengzhou 450044, China; zzwscl212@vip.163.com \\ * Correspondence: lichang@ncwu.edu.cn; Tel.: +86-371-69127378
}

check for updates

Citation: Li, C.; Zhang, X.; Zhang, B.; Tan, Y.; Li, F. Reuse of Sintered Sludge from Municipal Sewage Treatment

Plants for the Production of

Lightweight Aggregate Building Mortar. Crystals 2021, 11, 999.

https://doi.org/10.3390/

cryst11080999

Academic Editors: Shunbo Zhao, Juntao Ma and Shan Li

Received: 21 July 2021

Accepted: 19 August 2021

Published: 22 August 2021

Publisher's Note: MDPI stays neutral with regard to jurisdictional claims in published maps and institutional affiliations.

Copyright: (c) 2021 by the authors. Licensee MDPI, Basel, Switzerland. This article is an open access article distributed under the terms and conditions of the Creative Commons Attribution (CC BY) license (https:// creativecommons.org/licenses/by/ $4.0 /)$

\begin{abstract}
In recent years, the sludge produced by municipal sewage treatment plants has become an important recyclable resource for producing green building materials. After the systematic processing of incineration and particle formation, the sintered sludge can be processed into fine lightweight aggregate to produce building mortar with the controlled leaching of heavy metals and radioactivity. In this paper, to increase its economic and environmental benefits, mortar with sintered sludge aggregate was made by cement admixing of fly ash or limestone powder. The water-to-binder ratio was set at three levels- $0.82,0.68$, and 0.62 - and either flay ash or limestone powder was used to replace equal masses of cement at $10 \%, 20 \%$, or $30 \%$. Eighteen groups of mortar were studied to evaluate their workability, air content, compressive strength, tensile adhesive strength, dry density, and thermal conductivity. The results indicate that with a proper water-to-binder ratio, and the replacement ratio of fly ash or limestone powder, the mortar can be produced with good workability, consistency, water-retention rate, layering degree, and setting time. The mortar made with sintered sludge lightweight aggregate, designated by the mix-proportion method for conventional lightweight aggregate mortar, did not meet the target strength, although the compressive strength of mortar was no less than 3.0 MPa, which meets the strength grade M2.5. The tensile adhesive strength reached $0.18 \mathrm{MPa}$. The mortar was super lightweight with a dry density less than $400 \mathrm{~kg} / \mathrm{m}^{3}$, and a thermal conductivity within $0.30 \sim 0.32 \mathrm{~W} /(\mathrm{m} \cdot \mathrm{K})$. The effects of water-to-binder ratio and replacement ratio of fly ash or limestone powder on the above properties are discussed with test results. The study provides a basis for using sintered sludge lightweight aggregate for building mortar.
\end{abstract}

Keywords: municipal sewage sludge; sintered sludge; fine aggregate; super lightweight mortar; workability; dry density; air content; compressive strength; tensile adhesive strength; thermal conductivity

\section{Introduction}

Sludge is a product of sewage treatment, which is a complex composition of extremely heterogeneous organic fragments, bacteria, inorganic particles, and colloids. The increased quantity of sewage sludge has become a global environmental solid waste pollution problem. Normally, four disposal methods of sludge are used: agricultural utilization, sanitary landscaping, incineration, and building materials [1,2]. With the increasing requirements of the green utilization of sludge to ensure environmental protection, the two former disposal methods of sludge have been prohibited to avoid potential secondary pollution in many countries in recent years. Therefore, the disposal trends of sewage sludge are its incineration and its utilization in building materials [3-6]. 
The possibility of using sewage sludge for building materials comes from the similarity of its mineral components of $\mathrm{SiO}_{2}, \mathrm{Al}_{2} \mathrm{O}_{3}$, and $\mathrm{CaO}$ to conventional building materials. Therefore, raw sewage sludge can be used to directly replace clay and shale when producing bricks [7-13]. In this aspect, some of the expensive and energy-intensive stages of sludge disposal can be eliminated, and environmentally harmful waste can be transformed into safe and stable products $[4,5,14]$. Moreover, the organic-carbon-containing complexes of sewage sludge can be burned out, and the inorganic composites can then be reformed into ash or slag $[6,15,16]$. If blended with binder material, such as river sediment, to make pellets, a lightweight aggregate for concrete can be fabricated by incineration [17-20]. Comparatively, the sludge ash after incineration is always applied as a mineral additive to cement, or as a mineral admixture with concrete $[16,21,22]$. Slag treated as a fine-aggregate has been used in concrete products. Given the porosity and light weight of sintered sludge slag, the concrete products formed from it have better thermal and acoustic insulation properties so can be used for lightweight building walls [23-25].

As noted in a previous study [26], sintered sludge with the main component being silico-calcium was made from the municipal sewage produced by treatment plant of Zhengzhou City, China, by a systematic process of pellets formation and pyrolysis gasification at high temperature of about $1000{ }^{\circ} \mathrm{C}$. Through the second processing of crushing and polishing of the large particles, the sintered sludge was produced into a lightweight fine aggregate with a required particle grading of middle-class sand. The study confirmed that the sintered sludge fine aggregate met the criteria for heavy metal content and the radioactivity index, with no risk of leaching or radioactivity when recycled as a lightweight sand. Based on above literature analyses, lightweight sand can be used for masonry mortar meeting the requirement for autoclaved aerated concrete blocks [27-29]. With the combination of the environmental utilization of fly ash and limestone powder in mineral admixtures, this mortar can be produced with better economic and environmental benefits [30-32]. In this study, fine lightweight aggregate produced from sintered sludge was used in the production of masonry mortar. Eighteen groups of mortar were prepared with changes to both the water-to-binder ratio and the replacement ratio of either fly ash or limestone powder for cement at equal mass [33-35]. The workability and air content of fresh mortar, and the compressive strength, tensile adhesive strength, dry density, and thermal conductivity of hardened mortar, were measured using standard test methods [36,37]. The effects of the test factors on the above properties of mortar are discussed based on the test results. The study indicates the feasibility of producing mortar with fine-aggregate sintered sludge, and provides a route to reuse the sewage sludge as a building material.

\section{Experimental Work}

\subsection{Raw Materials}

The fine aggregate was made of sintered sludge with continuous particles in grading that met the requirement for building fine aggregate, as presented in Figure 1. The physical properties of the fine aggregate are presented in Table 1. According to the specification of Chinese codes GB/T14684 and GB/T17431.1 [38,39], the fine aggregate belongs to middle sand with particle grading in region-II in the 900 density class. Due to the large percentage of apertures distributed on the surface of the aggregates, the fine aggregate is featured by fast saturation with water absorption. The water absorption at $15 \mathrm{~min}$ and $1 \mathrm{~h}$ was $17.1 \%$ and $17.4 \%$, respectively, reaching about $87.7 \%$ and $89.2 \%$ at 24 hours, respectively. 


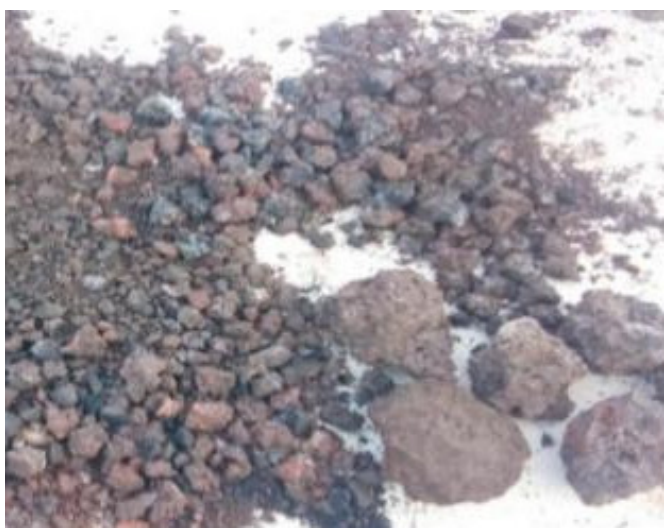

(a)

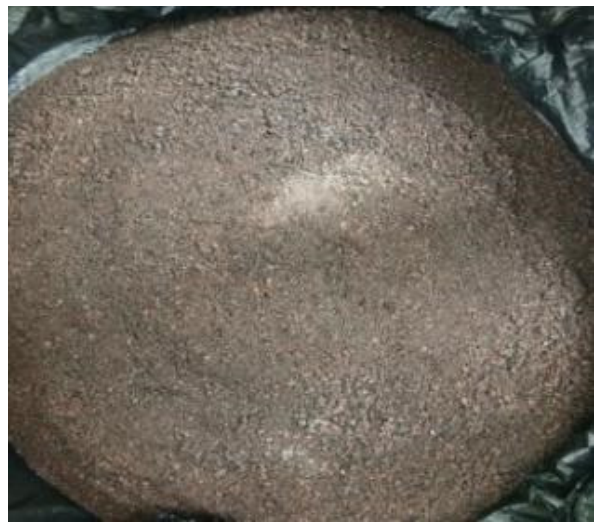

(b)

Figure 1. Photos of sintered sludge: (a) a prototype of sintered sludge; (b) graded fine aggregate.

Table 1. Physical properties of the fine, lightweight aggregate sintered sludge.

\begin{tabular}{cccccc}
\hline $\begin{array}{c}\text { Fineness } \\
\text { Modulus }\end{array}$ & $\begin{array}{c}\text { Apparent Density } \\
\left(\mathbf{k g} / \mathbf{m}^{\mathbf{3}}\right)\end{array}$ & $\begin{array}{c}\text { Bulk Density } \\
\left(\mathbf{k g} / \mathbf{m}^{\mathbf{3}}\right)\end{array}$ & $\begin{array}{c}\text { Mud Content } \\
(\mathbf{\%})\end{array}$ & $\begin{array}{c}\text { Moisture Content } \\
(\mathbf{\%})\end{array}$ & $\begin{array}{c}\text { Porosity } \\
(\mathbf{\%})\end{array}$ \\
\hline 2.6 & 2103 & 869 & 2.2 & 1.0 & 44.7 \\
\hline
\end{tabular}

The binders used were grade 42.5 Portland cement, second-class fly ash (FA), and first-class limestone powder (LP). The chemical components are presented in Table 2. The physical and mechanical properties are presented in Tables 3 and 4 . The properties met the specifications of Chinese codes GB/T1596, GB/T35164, and GB175 [31,32,40].

Table 2. Chemical compositions of cement, fly ash, and limestone powder.

\begin{tabular}{ccccccccc}
\hline Property & $\mathrm{SiO}_{\mathbf{2}}$ & $\mathrm{Fe}_{\mathbf{2}} \mathbf{O}_{\mathbf{3}}$ & $\mathrm{Al}_{\mathbf{2}} \mathbf{O}_{\mathbf{3}}$ & $\mathrm{CaO}$ & $\mathbf{M g O}$ & $\mathbf{S O}_{3}$ & f-CaO & Loss on Ignition \\
\hline Cement & 20.81 & 3.28 & 5.99 & 60.12 & 2.13 & 2.23 & 0.67 & 3.5 \\
$\mathrm{FA}$ & 55.92 & 5.91 & 17.31 & 6.59 & 3.82 & 1.93 & 0.26 & 2.6 \\
$\mathrm{LP}$ & 0.89 & 1.44 & 6.27 & 47.78 & 0.48 & 27.38 & 6.65 & 5.51 \\
\hline
\end{tabular}

Table 3. Physical and mechanical properties of cement.

\begin{tabular}{|c|c|c|c|c|c|c|c|c|c|c|c|}
\hline \multirow{2}{*}{$\begin{array}{l}\text { Density } \\
\left(\mathrm{g} / \mathrm{cm}^{3}\right)\end{array}$} & \multirow{2}{*}{$\begin{array}{c}\text { Water for } \\
\text { Standard } \\
\text { Consistency }(\%)\end{array}$} & \multirow{2}{*}{$\begin{array}{c}\text { Specific } \\
\text { Surface Area } \\
\left(\mathrm{m}^{2} / \mathrm{kg}\right)\end{array}$} & \multirow{2}{*}{$\begin{array}{l}\text { Fluidity } \\
\text { (mm) }\end{array}$} & \multicolumn{2}{|c|}{$\begin{array}{l}\text { Setting Time } \\
\text { (min) }\end{array}$} & \multicolumn{3}{|c|}{$\begin{array}{c}\text { Compressive Strength } \\
(\mathrm{MPa})\end{array}$} & \multicolumn{3}{|c|}{$\begin{array}{c}\text { Flexural Strength } \\
(\mathrm{MPa})\end{array}$} \\
\hline & & & & Initial & Final & $3 d$ & $7 d$ & $28 d$ & $3 d$ & $7 d$ & $28 d$ \\
\hline 3.09 & 27 & 360 & 164 & 170 & 215 & 27.5 & 39.2 & 58.5 & 5.4 & 6.8 & 8.3 \\
\hline
\end{tabular}

Table 4. Physical properties of fly ash and limestone powder.

\begin{tabular}{|c|c|c|c|c|c|c|c|c|}
\hline \multirow{2}{*}{ Material } & \multirow{2}{*}{$\begin{array}{c}\text { Apparent } \\
\text { Density } \\
\left(\mathrm{kg} / \mathrm{m}^{3}\right)\end{array}$} & \multirow{2}{*}{$\begin{array}{l}\text { Specific Surface } \\
\text { Area }\left(\mathrm{m}^{2} / \mathrm{kg}\right)\end{array}$} & \multicolumn{2}{|c|}{ Activity Index (\%) } & \multirow{2}{*}{$\begin{array}{c}\text { Water } \\
\text { Demand } \\
\text { Ratio (\%) }\end{array}$} & \multirow{2}{*}{$\begin{array}{l}\text { Mobility } \\
\text { Ratio (\%) }\end{array}$} & \multicolumn{2}{|c|}{$\begin{array}{c}\text { Fineness: Residual on } \\
\text { Sieve }(\%)\end{array}$} \\
\hline & & & $7 \mathrm{~d}$ & $28 \mathrm{~d}$ & & & $80 \mu \mathrm{m}$ & $45 \mu \mathrm{m}$ \\
\hline FA & 2340 & 406 & - & 73.3 & 84 & - & 5.48 & 21.75 \\
\hline LP & 2780 & 428 & 62.6 & 61.6 & - & 103 & 1.20 & 25.00 \\
\hline
\end{tabular}

The plasticizer produced by Kezijie New Materials Co. Ltd. (Zhengzhou, China), was selected for the comparison tests. The consistency was $95.6 \mathrm{~mm}$, the water-retention rate was $90.9 \%$, and the compressive strength at 7 days was $2.05 \mathrm{MPa}$. The properties met the specification of Chinese code JG/T164 [41]. The mix water used was tap water. 


\subsection{Mix Proportion Design of Building Mortars}

According to the design method for mixing proportions of masonry mortar, as specified in China code JGJ/T98 [33], building mortar with a strength grade of M2.5 and M5 should reach a target compressive strength of 3.0 and $6.0 \mathrm{MPa}$, respectively. After the calculations, three water-to-binder ratios were taken: $0.82,0.68$ and 0.62 . The dosage of binder was 330,380 , and $420 \mathrm{~kg} / \mathrm{m}^{3}$, respectively. After trial tests, the fly ash and limestone powder were separately used as the mineral admixture to replace cement in equal mass in percentage of $10 \%, 20 \%$, or $30 \%$. Under the condition of surface drying saturation of the fine aggregate in the mix design, the additional water computed for 1 hour water absorption was added for pre-wetting the fine aggregate before mixing. The mix proportion of the mortars is presented in Table 5 .

Table 5. Mix proportions of the mortars with fine-aggregate sintered sludge.

\begin{tabular}{|c|c|c|c|c|c|c|}
\hline \multirow{2}{*}{$\begin{array}{c}\text { Water to } \\
\text { Binder Ratio }\end{array}$} & \multicolumn{6}{|c|}{ Dosage of Materials $\left(\mathrm{kg} / \mathrm{m}^{3}\right)$} \\
\hline & Cement & FA or LP & Fine Aggregate & Water & Plasticizer & $\begin{array}{c}\text { Additional } \\
\text { Water }\end{array}$ \\
\hline \multirow{4}{*}{0.82} & 297 & 33 & 939 & 270 & 8.5 & 149.1 \\
\hline & 264 & 66 & 939 & 270 & 8.5 & 149.1 \\
\hline & 231 & 99 & 939 & 270 & 8.5 & 149.1 \\
\hline & 342 & 38 & 939 & 260 & 8.5 & 149.1 \\
\hline \multirow[t]{2}{*}{0.68} & 306 & 76 & 939 & 260 & 8.5 & 149.1 \\
\hline & 266 & 114 & 939 & 260 & 8.5 & 149.1 \\
\hline \multirow{3}{*}{0.62} & 378 & 42 & 939 & 260 & 8.5 & 149.1 \\
\hline & 336 & 84 & 939 & 260 & 8.5 & 149.1 \\
\hline & 294 & 126 & 939 & 260 & 8.5 & 149.1 \\
\hline
\end{tabular}

\subsection{Test Methods}

The fine aggregate was pre-wetted with the additional water in the mixer for $15 \mathrm{~min}$. Then the binders, plasticizer, and mix water were added to mix together to prepare the mortar. As per China code JGJ/T70 [36], the workability of fresh mortar was detected, including consistency, layering degree, setting time and water-retention rate. The air content was measured to verify the rational plasticizer content. The dry density and compressive strength of the hardened mortar were measured in cubic specimens with a dimension of $70.7 \mathrm{~mm}$. The tensile adhesive strength of hardened mortar was tested with $40 \times 40 \times 6 \mathrm{~mm}$ specimens. The thermal conductivity of the hardened mortar was determined using the transient plane heat source method [37], and cubic specimens with a dimension of $70.7 \mathrm{~mm}$ were used. Before detection, the specimen was dried to a constant weight, and the surface was polished. The diameter of the probe was $9.868 \mathrm{~mm}$, and the over-rise of the temperature was $2-5 \mathrm{~K}$.

\section{Test Results and Discussion}

\subsection{Workability of Fresh Mortar}

Figure 2 presents the test results of the workability of the fresh mortars. All mortars satisfied the target consistency of $60-80 \mathrm{~mm}$ and the water-retention rate of no less than $84 \%[34,35]$. This indicates that the workability of the test mortars was less affected by the sintered sludge aggregate with features such as an irregular shape, multiple edges, and greater water absorption compared to the targets designated by methods for producing conventional and lightweight masonry mortar with common lightweight. The conventional relationships were observed of the increased consistency and decreased water-retention rate of mortar with the increase in water-to-binder ratio. Higher flowability of fresh mortar can be obtained with a larger water-to-binder ratio, while the layering degree was lower and the setting time increased. All mortars met the expected layering degree of no more than $30 \mathrm{~mm}[34,35]$. With an expected setting time of 4 to $8 \mathrm{~h}$, the water-to-binder ratio should be no more than 0.68 for the mortar without admixing fly ash or limestone powder. 


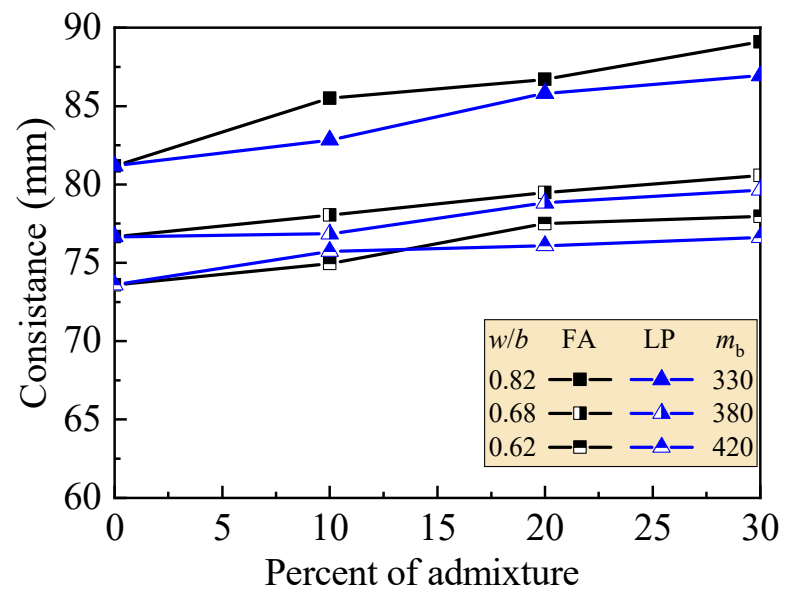

(a)

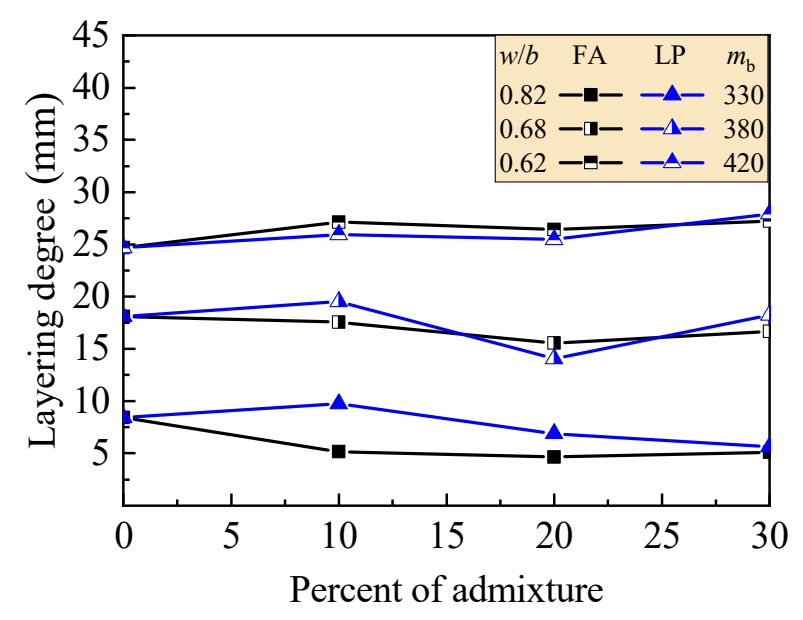

(c)

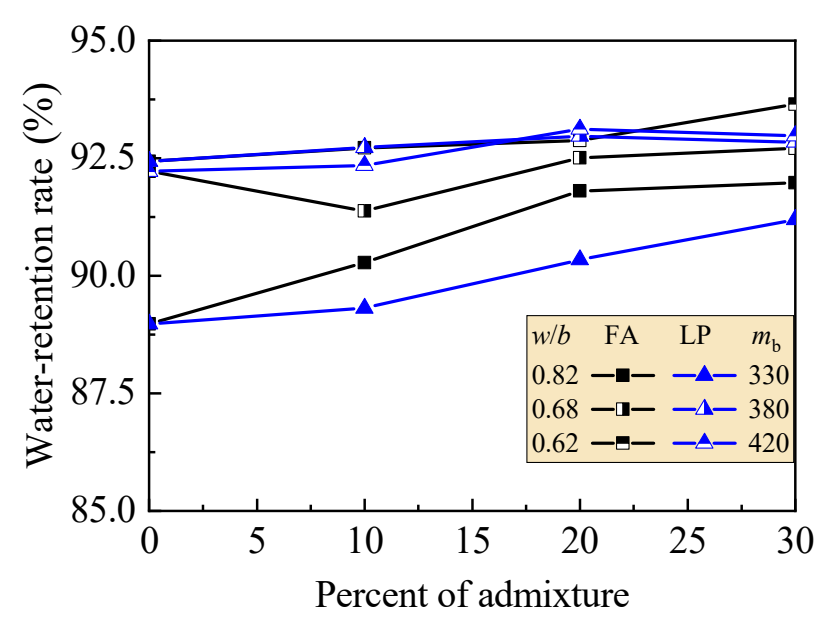

(b)

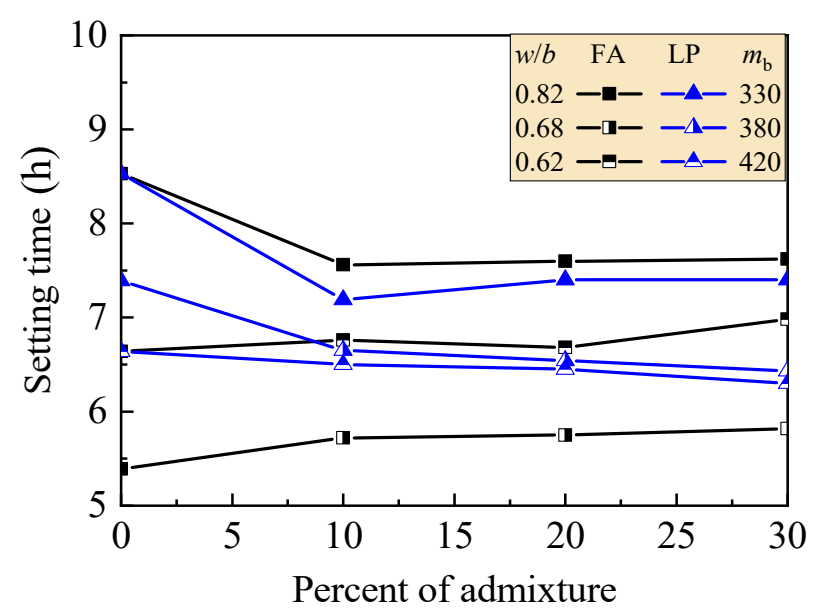

(d)

Figure 2. Test results of workability of fresh mortars: (a) consistency; (b) water-retention rate; (c) layering degree; (d) setting time.

With an increase in the replacement ratio of fly ash and limestone powder from $10 \%$ to $30 \%$, the consistency and water-retention rate also increased. This resulted from the peculiarity of fly ash and limestone powder, having smaller particles and a greater surface area. The free water in fresh mortar increased due to the intervals being filled with smaller grains of fly ash or limestone powder becoming locked in the internal fresh mortar $[30,42]$. With good consistency and water retention, the layering degree of fresh mortar was slightly influenced by the replacement ratio of both fly ash and limestone powder. When the water-to-binder ratio was 0.62 , the layering degree of fresh mortar tended to increase with the increasing replacement ratio of both fly ash and limestone powder. However, the layering degree of the mortars containing 30\% fly ash or limestone powder was below the limit of $30 \mathrm{~mm}$. The setting time for fresh mortars with a water-to-binder ratio of 0.82 became shorter due to the presence of either fly ash or limestone powder. This may have been a combined effect of the crystal nuclei in fly ash and limestone powder and specific pozzolanic activity $[30,42,43]$, which accelerated the hydration of cement, leading to the formation of crystals.

\subsection{Air Content}

The changes in the air content of fresh mortars using a replacement ratio of fly ash or limestone powder are presented in Figure 3. Changing the replacement ratio in fresh 
mortars with the same water-to-binder ratio had less of an influence on their air content. However, the air content in the fresh mortar increased with an increase in the water-tobinder ratio. This ensured that the mortar had better water retention when the water-tobinder ratio increased to 0.82 . With an increase in the replacement ratio using fly ash, the air content increased about $1 \%$. However, with a replacement ratio of limestone powder at $10 \%$, the air content in the fresh mortar decreased. This was due to an aggregate effect of the limestone powder on the density of the binder paste [30,42]. The same effect happened in fresh mortar using a replacement ratio of limestone powder at $20 \%$ and a water-tobinder ratio of 0.82 . When the replacement ratio increased to $30 \%$, the fresh mortar's air content was almost higher compared with the mortar made without admixing fly ash or limestone powder.

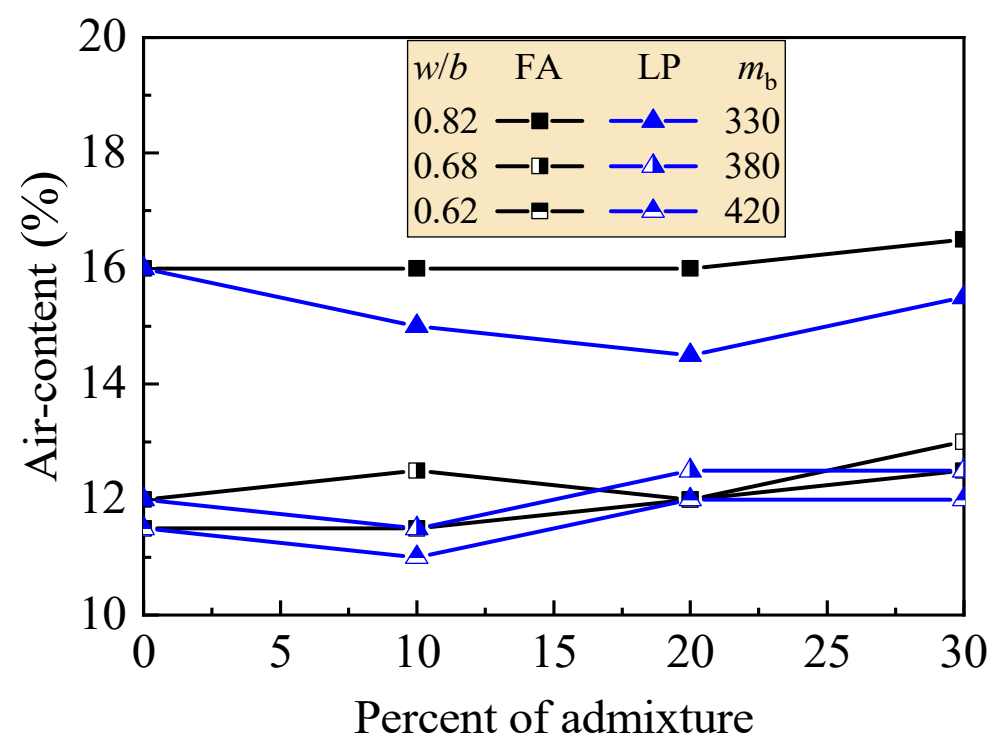

Figure 3. Test results of the air content of fresh mortars.

\subsection{Compressive Strength}

The test results of the compressive strength of mortar at curing ages of 14 and 28 days are presented in Figure 4. The conventional relationship shows that the compressive strength increased with the decrease in water-to-binder ratio for the mortar with sintered sludge lightweight aggregate. Compared to the test results at a curing age of 28 days, the compressive strength of mortar at 14 days was affected much more by the replacement of fly ash and limestone powder. Due to the differences in the chemical compositions and activity indices, different effects were observed for fly ash and limestone powder.

The compressive strength of mortar at the curing age of 14 days increased with the replacement ratio of $10 \%$ fly as, due to the activity of fly ash from the second hydration of the main chemical constituent, $\mathrm{SiO}_{2}$, with the hydration product $\mathrm{Ca}(\mathrm{OH})_{2}$ of cement $[30,43]$. When the replacement ratio increased continuously to $20 \%$ and $30 \%$, the compressive strength of the mortar decreased. This may be due to the inadequate hydration product $\mathrm{Ca}(\mathrm{OH})_{2}$ with the decrease in cement dosage in mortar. In this case, although the compressive strength of the mortar may be increased by the small aggregate effect of fly ash on the density of the mortar, the increase could not compensate for the decrease in compressive strength. 


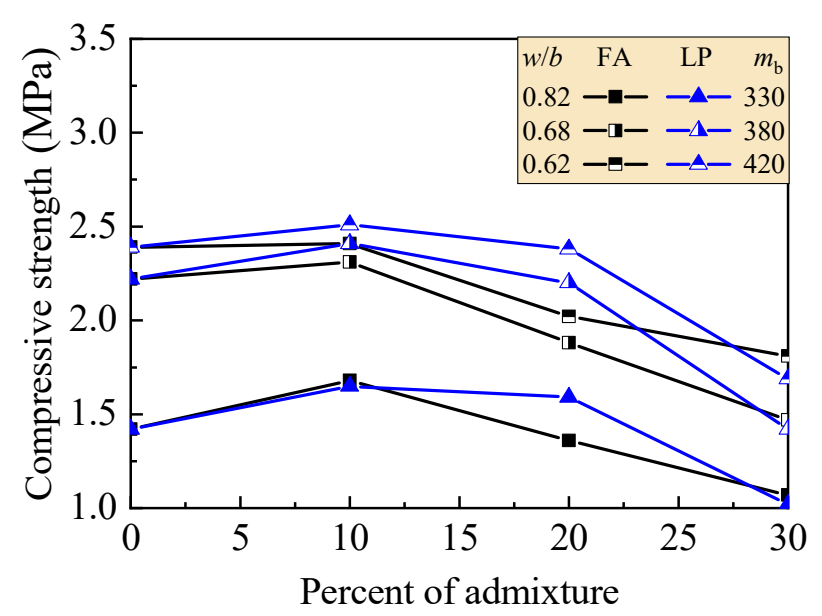

(a)

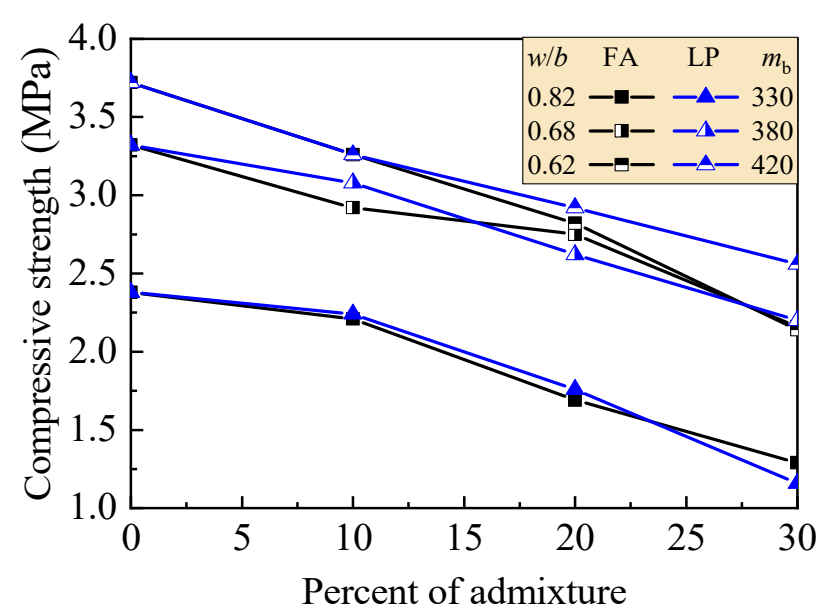

(b)

Figure 4. Test results of the compressive strength of mortars: (a) at a curing age of 14 days; (b) at a curing age of 28 days.

With a higher content of $\mathrm{f}-\mathrm{CaO}$ and $\mathrm{CaO}$, as presented in Tables 2 and 4, limestone powder had higher activity at an early age when used to produce cement stone. This resulted in an increase in the mortar's compressive strength at a curing age of 14 days when the replacement ratio was $10 \%$. Combined with the crystal nuclei and tiny-aggregate filling effects, the mortar with a replacement ratio of $20 \%$ limestone powder had almost the same compressive strength as the mortar made without limestone powder.

Similar to the time-dependent compressive strength of concrete [44], the compressive strength of the mortar increased with the increase in curing age from 14 to 28 days. However, with the curing age of 28 days, the activity of fly ash and limestone powder no longer enhanced the compressive strength of the mortar. This trend of decreased compressive in appeared for the mortars with an increased replacement ratio of either fly ash or limestone powder. This indicates that the main source of crystals was the hydration of the cement. Due to a decrease in cement dosage, along with an increase in the replacement ratio of fly ash and limestone powder, the shortage of cement-forming crystals could not be accounted for by the contribution of fly ash and limestone powder with a combination of pozzolanic activity, crystal nuclei, and tiny-aggregate filling effects.

From the test results of compressive strength, no mortar met the target M5 strength requirement. This indicates that the mortar with sintered sludge lightweight aggregate had a lower compressive strength than the target designated by the mix-proportion method for mortars made with conventional lightweight aggregate. However, the mortars with a water-to-binder ratio of 0.62 and a replacement ratio of no more than $20 \%$ and those with a water-to-binder ratio of 0.68 and a replacement ratio of no more than $10 \%$ met the target strength of M2.5.

\subsection{Tensile Adhesive Strength}

The test results for the tensile adhesive strength of mortar at a curing age of 28 days are presented in Figure 5. Without admixing fly ash or limestone powder, the mortar's tensile adhesive strength increased with decreasing water-to-binder ratio. This relationship was maintained when limestone powder was added, but disturbed when fly ash was added. This reflects the different actions of fly ash and limestone powder in the mortar's internal structure [45]. However, with an increase in the replacement ratio of either fly ash or limestone powder, the mortar's tensile adhesive strength generally decreased. A lower tensile adhesive strength was found for the mortar with limestone powder at a water-to-binder ratio of no less than 0.68 . Due to the lower activity of fly ash and limestone powder, no adequate crystals formed from their hydration of them to compensate for the decrease with the decreased dosage of cement. 


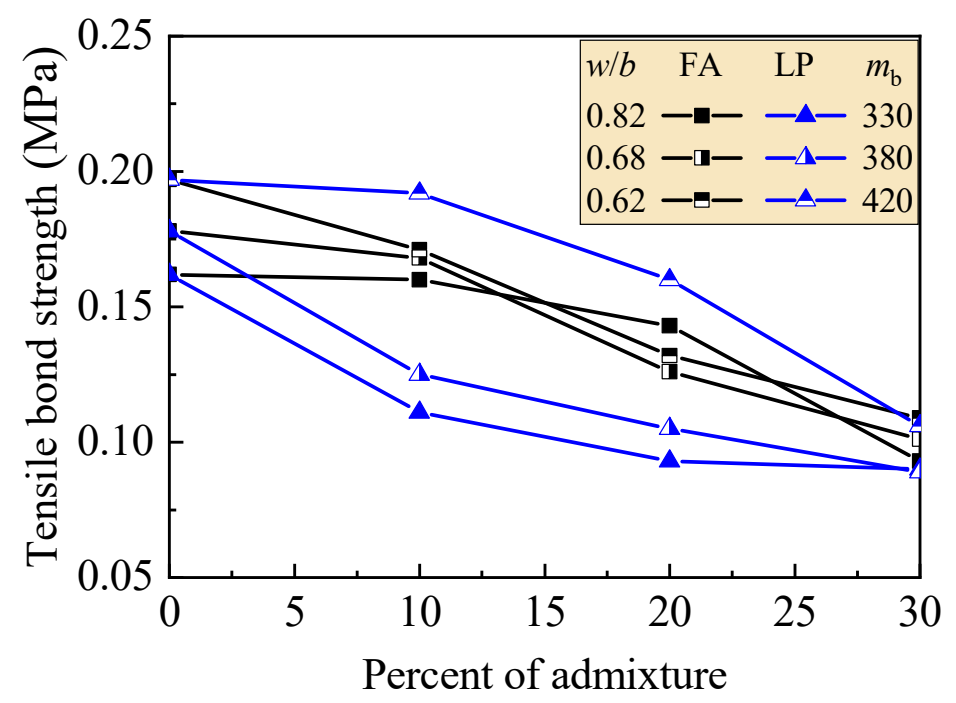

Figure 5. Test results of the tensile adhesive strength of mortars.

The mortar made with sintered sludge lightweight aggregate presented a lower tensile adhesive strength than the target. According to the test results for tensile adhesive strength, no mortar in this study met the target tensile adhesive strength of no less than $0.20 \mathrm{MPa}$ for masonry mortar [34,35]. However, the mortars with replacement ratios of $10 \%$ fly ash with a water-to-binder ratio no more than 0.68 and the mortars with replacement ratios of $10 \%$ limestone powder with a water-to-binder ratio of 0.62 met the target value of $0.18 \mathrm{MPa}$ for plastering mortar of autoclaved aerated concrete walls [35].

\subsection{Dry Density and Thermal Coductivity}

The test results of the dry density and thermal conductivity of the test mortars are presented in Figure 6. The dry density of mortar presents a decreased trend with the increase in the replacement ratio of either fly ash or limestone powder. This may be mainly due to the lower density of fly ash and limestone powder than that of cement, as presented in Tables 3 and 4. With an equal mass of cement, the volume of fly ash and limestone powder is larger than that of cement. So, the density of mortar is lower. In this study, the dry density of mortar was below $370 \mathrm{~kg} / \mathrm{m}^{3}$. Therefore, a super lightweight mortar can be produced using the fine aggregate of sintered sludge.

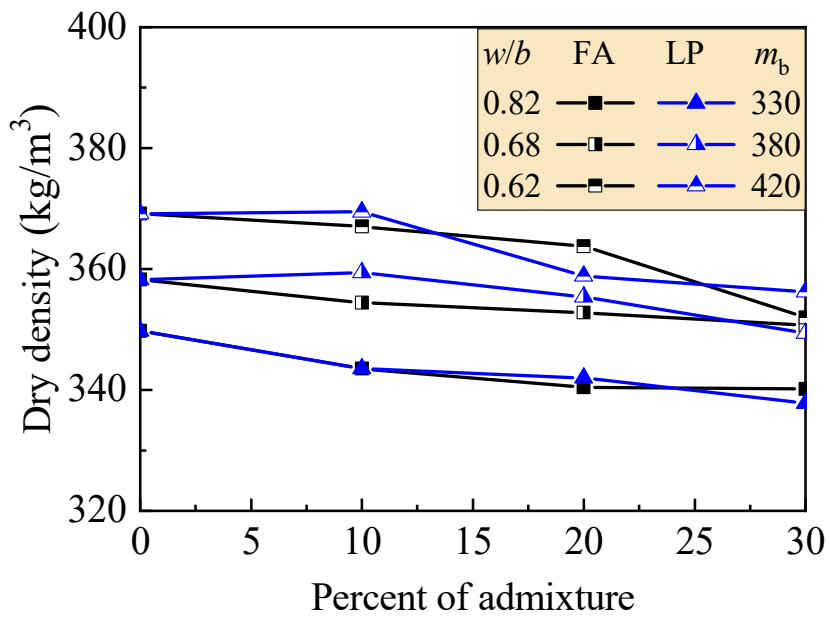

(a)

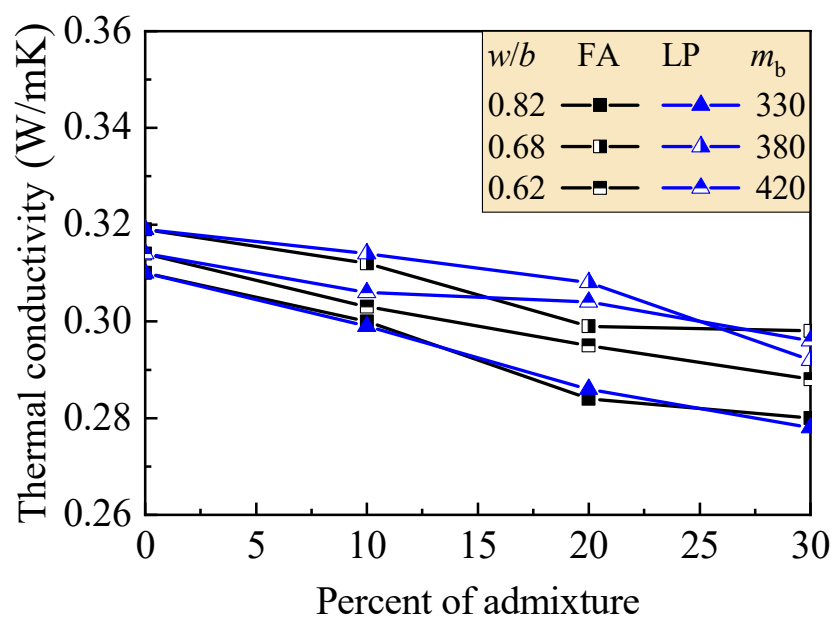

(b)

Figure 6. Test results of the compressive strength of mortars: (a) dry density; (b) thermal conductivity. 
The mortar with a water-to-binder ratio of 0.82 presented the lowest thermal conductivity, while the mortar with a water-to-binder ratio of 0.68 presented the highest thermal conductivity. The mortar with a water-to-binder ratio of 0.62 had a value of thermal conductivity between the values stated above. This indicates that the thermal conductivity of mortar is not only related to its density, but that it is also dependent on its the pore structure [24,27]. The mortar's air content presented in Figure 3 may be suitable at about $12 \%$ to form an ideal internal bubble distribution in the mortar. In terms of meeting the requirement of $\mathrm{M} 2.5$, the thermal conductivity of mortar can be controlled within $0.30-0.32 \mathrm{~W} /(\mathrm{m} \cdot \mathrm{K})$.

\section{Conclusions}

Based on the experimental investigation in this study, conclusions were drawn as follows:

(1) The mortar made with fine lightweight aggregate of sintered sludge satisfied the target consistency of $60-80 \mathrm{~mm}$ and the water-retention rate of no less than $84 \%$. The workability of the test mortar was less affected by the sintered sludge aggregate with features such as irregular shape, multi-edges, and greater water absorption. However the consistency and water-retention rate increased with an increase in the replacement ratio of fly ash or limestone powder ranging from $10 \%$ to $30 \%$.

(2) A lower strength was obtained for the mortar made with sintered sludge lightweight aggregate than the target designed using the mix-proportion method for mortars made with conventional lightweight aggregate under the same conditions. The mortars with a water-to-binder ratio of 0.62 and a replacement ratio of no more than $20 \%$, and the mortars with a water-to-binder ratio of 0.68 and a replacement ratio of no more than $10 \%$ met the target strength of grade M2.5. No mortar in this study met the target tensile adhesive strength of no less than $0.20 \mathrm{MPa}$ for masonry mortar. However, the mortars with replacement ratios of $10 \%$ fly ash with a water-to-binder ratio of no more than 0.68 , and the mortars with a replacement ratio of $10 \%$ limestone powder with a water-to-binder ratio of 0.62 met the target value of $0.18 \mathrm{MPa}$ for plastering mortar used in autoclaved aerated concrete walls.

(3) The dry density of the mortar was below $370 \mathrm{~kg} / \mathrm{m}^{3}$. Therefore, a super lightweight mortar can be produced using a fine lightweight aggregate made from sintered sludge. The air content for mortar may be suitable at a value of about $12 \%$. For cases of meeting the requirement of M2.5, the thermal conductivity of mortar can be controlled within $0.30-0.32 \mathrm{~W} /(\mathrm{m} \cdot \mathrm{K})$.

(4) The experimental study in this paper is initial research into the feasibility of the use fine lightweight aggregate of sintered sludge in building mortar. To obtain further economic and environmental benefits from the recycling of solid waste, producing mortars made with sintered sludge lightweight aggregate by admixing fly ash or limestone powder is a valuable method. Further studies should be carried out to optimize the incineration techniques of sludge and the mix-proportion of mortar to meet the requirements of these specifications.

Author Contributions: Methodology, F.L. and Y.T.; tests, data interpretation and writing-original draft, C.L., X.Z. and B.Z.; writing-review and funding acquisition, F.L. and Y.T. All authors have read and agreed to the published version of the manuscript.

Funding: This research was funded by the Henan Provincial Special Project of Key Sci-Tech Research and Development Promotion, China (grant number 212102310272); the Key Scientific Research Project in Universities of Henan, China (grant number 19A560012); and the Innovative Sci-Tech Team of Eco-building Material and Structural Engineering of Henan Province, China (grant number YKRZ-6-066).

Institutional Review Board Statement: Not applicable.

Informed Consent Statement: Not applicable. 
Data Availability Statement: Data are contained within the article.

Conflicts of Interest: The authors declare no conflict of interest.

\section{References}

1. Hudson, J.A.; Lowe, P. Current technologies for sludge treatment and disposal. Water Environ. J. 1996, 10, 436-441. [CrossRef]

2. General Administration of Quality Supervision of the People's Republic of China. Disposal of Sludge from Municipal Wastewater Treatment Plant-Classification; GB/T23484-2009; China Standard Press: Beijing, China, 2009.

3. Qian, J.S.; Xie, C.B.; Xie, X.L.; Chen, W.; Yang, H.L. Utilization of municipal sewage sludge as building materials: A state-of-the-art review. J. Build. Mater. 2014, 17, 829-836.

4. Paris, J.M.; Roessler, J.G.; Ferraro, C.C.; DeFord, H.D.; Townsend, T.G. A review of waste products utilized as supplements to Portland cement in concrete. J. Clean. Prod. 2016, 121, 1-18. [CrossRef]

5. Świerczek, L.; Cieślik, B.M.; Konieczka, P. The potential of raw sewage sludge in construction industry-A review. J. Clean. Prod. 2018, 200, 342-356. [CrossRef]

6. Schnell, M.; Horst, T.; Quicker, P. Thermal treatment of sewage sludge in Germany: A review. J. Environ. Manag. 2020, 263, 110367. [CrossRef] [PubMed]

7. Chang, Z.Y.; Long, G.C.; Zhou, J.L.; Ma, C. Valorization of sewage sludge in the fabrication of construction and building materials: A review. Resour. Conserv. Recycl. 2020, 154, 104606. [CrossRef]

8. Weibusch, B. Utilization of sewage sludge ashes in the brick and tile industry. Water Sci. Technol. 1997, 36, 243-250. [CrossRef]

9. Lin, D.-F.; Weng, C.-H. Use of sewage sludge ash as brick material. J. Environ. Eng. 2001, 127, 922-927. [CrossRef]

10. Fan, Y.R.; Deng, C.; Luo, H.; Chen, W.; Qian, J.S. Experimental analysis on preparation of fired brick with shale and sewage sludge. J. Civ. Architect. Environ. Eng. 2012, 34, 130-135.

11. Huang, B.Z.; Lai, J.; Huang, B.B.; Zhu, J.Z. Experimental study on the effect to compressive strength of flux on sludge lightweight sintered shale brick. Adv. Mater. Res. 2014, 2837, 2330-2333. [CrossRef]

12. Velumani, P.; Senthilkumar, S. Production of sludge-incorporated paver blocks for efficient waste management. J. Air Waste Manag. Assoc. 2018, 6, 626-636. [CrossRef]

13. Esmeray, E.; Atıs, M. Utilization of sewage sludge, oven slag and fly ash in clay brick production. Constr. Build. Mater. 2019, 194, 110-121. [CrossRef]

14. Gomes, S.D.C.; Zhou, J.L.; Li, W.G.; Qu, F.L. Recycling of raw water treatment sludge in cementitious composites: Effects on heat evolution, compressive strength and microstructure. Resour. Conserv. Recycl. 2020, 161, 104970. [CrossRef]

15. Tantawy, M.A.; El-Roudi, A.M.; Abdalla, E.M.; Abdelzaher, M.A. Evaluation of the pozzolanic activity of sewage sludge ash. ISRN Chem. Eng. 2012, 2012, 487037. [CrossRef]

16. Vouk, D.; Nakic, D.; Stirmer, N.; Cheeseman, C.R. Use of sewage sludge ash in cementitious materials. Rev. Adv. Mater. Sci. 2017, $49,158-170$.

17. Liu, M.W.; Xu, G.R.; Li, C.B. Effect of the ratio of components on the characteristics of lightweight aggregate made from sewage sludge and river sediment. Process Saf. Environ. Prot. 2017, 105, 109-116. [CrossRef]

18. Chiou, I.-J.; Wang, K.-S.; Chen, C.-H. Lightweight aggregate made from sewage sludge and incinerated ash. Waste Manag. 2006, 26, 1453-1461. [CrossRef] [PubMed]

19. Bhatty, J.I.; Reid, K.J. Moderate strength concrete from lightweight sludge ash aggregates. Int. J. Cem. Compos. Lightweight Concr. 1989, 11, 179-187. [CrossRef]

20. Nakic, D. Environmental evaluation of concrete with sewage sludge ash based on LCA. Sustain. Prod. Consum. 2018, 16, 193-201. [CrossRef]

21. Baeza-Brotons, F.; Garcès, P.; Payà, J.; Saval, J.M. Portland cement systems with addition of sewage sludge ash: Application in concretes for the manufacture of blocks. J. Clean. Prod. 2014, 82, 112-124. [CrossRef]

22. Zaleska, M.; Pavlik, Z.; Pavlikova, M.; Scheinherrova, L.; Pokorny, J.; Trnik, A.; Svora, P.; Fort, J.; Jankovsky, O.; Suchorab, Z. Biomass ash-based mineral admixture prepared from municipal sewage sludge and its application in cement composites. Clean Technol. Environ. Policy 2018, 1, 159-171. [CrossRef]

23. Khanbilvardi, R.; Afshari, S. Sludge ash as fine aggregate for concrete mix. Environ. Eng. Div. ASCE 1995, 121, 633-638. [CrossRef]

24. Wang, K.S.; Tseng, C.J.; Chiou, I. The thermal conductivity mechanism of sewage sludge ash lightweight materials. Cem. Concr. Res. 2005, 35, 803-809. [CrossRef]

25. Chesseman, C.R.; Virdi, G.S. Properties and microstructure of lightweight aggregate produced from sintered sewage sludge ash. Resour. Conserv. Recycl. 2005, 45, 18-30. [CrossRef]

26. Zhang, X.Y.; Zhang, B.X.; Liang, N.; Tan, Y.F.; Zhao, S.B. Experimental study on the feasibility of municipal sewage treatment sintered sludge uses for building fine aggregate. New Build. Mater. 2021, 4, 103-105.

27. Ministry of Housing and Urban-Rural Construction of the People's Republic of China. Technical Specification for Application of Autoclaved Aerated Concrete; JGJ/T17-2008; China Building Industry Press: Beijing, China, 2008.

28. Li, F.L.; Chen, G.L.; Zhang, Y.Y.; Hao, Y.C.; Si, Z.K. Fundamental properties and thermal transferability of masonry built by autoclaved aerated concrete self-insulation blocks. Materials 2020, 13, 1680. [CrossRef]

29. Liu, Y.; Chen, G.L.; Wang, Z.P.; Chen, Z.; Gao, Y.J.; Li, F.L. On the seismic performance of autoclaved aerated concrete selfinsulation block walls. Materials 2020, 13, 2942. [CrossRef] [PubMed] 
30. Li, F.L.; Liu, C.J.; Pan, L.Y.; Li, C.Y. Manufactured Sand Concrete; China Waterpower Press: Beijing, China, 2014.

31. General Administration of Quality Supervision, Inspection and Quarantine of the People's Republic of China. Fly Ash Used for Cement and Concrete; GB/T 1596-2017; China Standard Press: Beijing, China, 2017.

32. General Administration of Quality Supervision, Inspection and Quarantine of the People's Republic of China. Limestone Powder Used for Cement, Mortar, and Concrete; GB/T 35164-2017; China Standard Press: Beijing, China, 2017.

33. Ministry of Housing and Urban-Rural Construction of the People's Republic of China. Specification for Mix Proportion Design of Masonry Mortar; JGJ/T98-2010; China Building Industry Press: Beijing, China, 2010.

34. Ministry of Housing and Urban-Rural Construction of the People's Republic of China. Dry-Mixed Masonry and Plastering Mortar of Building; JG/T291-2011; China Building Industry Press: Beijing, China, 2011.

35. Department of Housing and Urban-Rural Construction of Henan Province. Technical Specification for the System of Self-Insulation Block Walls; DBJ41/T100-2015; Zhengzhou University Press: Zhengzhou, China, 2015.

36. Ministry of Housing and Urban-Rural Construction of the People's Republic of China. Standard for Test Method of Performance on Building Mortar; JGJ/T70-2009; China Building Industry Press: Beijing, China, 2009.

37. General Administration of Quality Supervision, Inspection and Quarantine of the People's Republic of China. Determination of Thermal Conductivity and Thermal Diffusivity of Building Materials: Transient Plane Heat Source Method; GB/T32064-2015; China Standard Press: Beijing, China, 2015.

38. General Administration of Quality Supervision of the People's Republic of China. Building Sand; GB/T14684-2011; Standards Press of China: Beijing, China, 2011.

39. General Administration of Quality Supervision of the People's Republic of China. Lightweight Aggregates and Its Test Methods-Part 1: Lightweight Aggregates; GB/T17431.1-2010; Standards Press of China: Beijing, China, 2011.

40. General Administration of Quality Supervision, Inspection and Quarantine of the People's Republic of China. Common Portland Cement; GB 175-2007; China Standard Press: Beijing, China, 2007.

41. Ministry of Housing and Urban-Rural Construction of the People's Republic of China. Masonry Mortar Plasticizer; JG/T164-2004; China Standard Press: Beijing, China, 2004.

42. Li, F.L.; Liang, N.; Li, C.Y. Effects of polypropylene fiber and stone powder of machine-made sand on resistance of cement mortar to cracking. J. Basic Sci. Eng. 2012, 20, 895-901.

43. Ding, X.X.; Lu, Y.Z.; Han, B.; Zhao, M.S.; Chen, M.H.; Zhao, S.B. Influence coefficient of fly ash for determination of binder strength in mix proportion design of concrete. In Architectural Engineering and New Materials (ICAENM 2015); Destech Publications, Inc.: Lancaster, PA, USA, 2015; pp. 115-123.

44. Ding, X.X.; Li, C.Y.; Xu, Y.Y.; Li, F.L.; Zhao, S.B. Experimental study on long-term compressive strength of concrete with manufactured sand. Constr. Build. Mater. 2016, 108, 67-73. [CrossRef]

45. Li, C.Y.; Yang, Y.B.; Su, J.Z.; Meng, H.D.; Pan, L.Y.; Zhao, S.B. Experimental research on interfacial bonding strength between vertical cast-in-situ joint and precast concrete walls. Crystals 2021, 11, 494. [CrossRef] 